\title{
A POSTMORTEM STUDY ON THE VOLUME OF THE HUMAN KIDNEY
}

\author{
JOHORA F ${ }^{1}$, NURUNNABI ASM ${ }^{2}$, SIDDIQUA D ${ }^{3}$, HENA H $^{4}$, ARA S $^{5}$
}

\begin{abstract}
:
Context: Kidney volume is a sensitive index of kidney size for the detection of renal abnormalities. It is also excellent predictor of renal function and correlates very well with body indexes. The present study was done on cadaveric specimens to see the age related changes in the volume of the kidney in a Bangladeshi population and to compare with the previous local and foreign studies.

Methods: This cross-sectional, descriptive study was done in the Department of Anatomy, Dhaka Medical College, Dhaka, from July 2008 to June 2009, based on collection of 140 post mortem human kidneys from 70 unclaimed dead bodies which were in the morgue under examination in the Department of Forensic Medicine, Dhaka Medical College, Dhaka. All the samples were divided into three age groups including A (10-19 years), B (20-39 years) and C (40-59 years). The length, breadth and thickness of each kidney were measured by using a slide calipers and recorded. Then the volume was determined by using prolate ellipsoid formula i.e. length $\times$ breadth $\times$ thickness $\times 0.52$.

Results: The volume of the right and left kidneys were found $54.46 \pm 4.02 \mathrm{~cm}^{3}$ and $53.15 \pm 1.98$ $\mathrm{cm}^{3}$ in group $A, 78.31 \pm 10.41 \mathrm{~cm}^{3}$ and $75.90 \pm 8.32 \mathrm{~cm}^{3}$ in group $B, 74.47 \pm 6.22 \mathrm{~cm}^{3}$ and $73.34 \pm 6.80 \mathrm{~cm}^{3}$ in group C. No statistically significant difference was found between the right and the left kidney in any group. However, statistically significant differences were evident between $A \& B$ and $A \& C(P<0.001)$.

Conclusion: No difference was found in volume between the right and the left kidney in any group. However, kidney volume was found to increase with advancing age in apparently healthy Bangladeshi people.
\end{abstract}

Key words: Human kidney, volume of kidney.

J Dhaka Med Coll. 2014; 23(1) : 73-77.

\section{Introduction:}

The determination of kidney size is important in clinical field, because it can facilitate to make decisions on the management strategy ${ }^{1}$. Kidney volume is a more sensitive index of kidney size for the detection of renal abnormalities $^{2}$. It is also excellent predictor of renal function and correlates very well with body indexes ${ }^{3}$. Furthermore, pre-transplant kidney volume is an independent determinant of the prognosis of the graft kidney ${ }^{4}$. Assessment of the kidney size or volume with advancing age can be performed with autopsy, ultrasound and computed tomography, in apparently healthy individuals. As with autopsy studies, imaging studies in populations that exclude persons with comorbidity show less decline in the kidney volume with age than the studies that do not have this exclusion ${ }^{5}$. Due to the complexity in kidney shape ${ }^{6}$, the calculation by using ellipsoid formula, however, sometimes tends to underestimate kidney volume ${ }^{7,8}$. Still we proposed prolate ellipsoid formula for measurement of kidney volume, as it is more convenient and widely used. Moreover, no data are available on volume of

1. Dr. Fatema Johora, Assistant Professor, Department of Anatomy, OSD, Directorate General of Health Services (DGHS), Dhaka.

2. Dr. Abu Sadat Mohammad Nurunnabi, Assistant Professor, Department of Anatomy, OSD, Directorate General of Health Services (DGHS), Dhaka.

3. Dr. Dilruba Siddiqua, Associate Professor, Department of Anatomy, Ibn Sina Medical College, Dhaka.

4. Dr. Hasna Hena, Associate Professor, Department of Anatomy, East-West Medical College, Dhaka.

5. Prof. Shamim Ara, Professor \& Head, Department of Anatomy, Dhaka Medical College, Dhaka.

Correspondence : Dr. Fatema Johora, Assistant Professor, Department of Anatomy, OSD, Directorate General of Health Services (DGHS), Dhaka. Cell Phone: +8801552306547. 
the kidney in healthy adult Bangladeshi people. Evidence showed that the morphological dimensions of different organs in Bangladeshi population have got variations from those of the western population ${ }^{9}$. Based on collection of cadaveric specimens, the aim of the present study was to see the variation in kidney volume with advancing age in a Bangladeshi population (who were not suffering from known kidney disease) and to compare with previous records of both local and foreign studies.

\section{Methods:}

This cross-sectional, descriptive study was done in the Department of Anatomy, Dhaka Medical College, Dhaka, from July 2008 to June 2009, based on collection of 140 post mortem human kidneys from 70 unclaimed dead bodies which were in the morgue under examination in the Department of Forensic Medicine, Dhaka Medical College, Dhaka. All the samples were collected from medicolegal cases excluding poisoning, any cutting or crushing injury to the kidneys, kidney found in one side or grossly abnormal in shape/size and from patients suffering from any kidney disease. For convenient description of changes in weight of the kidney in relation to age, the collected samples were divided into three agegroups including A (10-19 years), B (20-39 years) and C (40-59 years), according to Darmady et al. ${ }^{10}$ (table-I). The kidney was taken and its outer surface was dried with blotting paper. Then its length, breadth and thickness were measured by using a slide calipers and recorded. Then the volume was determined by using prolate ellipsoid formula i.e. length $\times$ breadth $\times$ thickness $\times 0.52$ (according to Emamian et al.) ${ }^{11}$. All data were recorded and processed. The comparison between right and left side was done by unpaired Student's ' $t$ ' test and the comparison between different groups was done by One-way ANOVA. All the statistical analyses were done by using the SPSS 13.0 version. This study was approved by the Ethical Review Committee of Dhaka Medical College, Dhaka.
Table-I

Age distribution of the samples of the present study $(n=140)$

\begin{tabular}{lccc}
\hline Age & Age limit & \multicolumn{2}{c}{ Number of samples } \\
\cline { 3 - 4 } group & in years & Right Kidney & Left kidney \\
\hline A & $10-19$ & 12 & 12 \\
B & $20-39$ & 43 & 43 \\
C & $40-59$ & 15 & 15 \\
\hline
\end{tabular}

\section{Results:}

The volume of the right and left kidneys were found $54.46 \pm 4.02 \mathrm{~cm}^{3}$ and $53.15 \pm 1.98 \mathrm{~cm}^{3}$ in group A (10-19 years), $78.31 \pm 10.41 \mathrm{~cm}^{3}$ and $75.90 \pm 8.32 \mathrm{~cm}^{3}$ in group B (20-39 years), $74.47 \pm 6.22 \mathrm{~cm}^{3}$ and $73.34 \pm 6.80 \mathrm{~cm}^{3}$ in group C (40-59 years) (table-II, fig. 1). No statistically significant difference was found between the right and left kidneys in any group. However, statistically significant differences were evident between A \& B and A \& C $(\mathrm{P}<0.001)$ (table-II).

\section{Table-II}

Volume of right and left kidney in different age group

\begin{tabular}{lccc}
\hline Age & \multicolumn{2}{c}{ Volume in $\mathrm{cm}^{3}$} & $\begin{array}{c}\mathrm{P} \\
\text { value }\end{array}$ \\
\cline { 2 - 3 } Group & $\begin{array}{c}\text { Right Kidney } \\
\text { Mean } \pm \text { SD }\end{array}$ & $\begin{array}{c}\text { Left Kidney } \\
\text { Mean } \pm \text { SD }\end{array}$ & \\
\hline A & $54.46 \pm 4.02$ & $53.15 \pm 1.98$ & $>0.10^{\text {ns }}$ \\
$(\mathrm{n}=12)$ & $(45.40-58.12)$ & $(48.50-54.90)$ & \\
B & $78.31 \pm 10.41$ & $75.90 \pm 8.32$ & $>0.10^{\text {ns }}$ \\
$(\mathrm{n}=43)$ & $(53.60-96.50)$ & $(59.10-98.20)$ & \\
C & $74.47 \pm 6.22$ & $73.34 \pm 6.80$ & $>0.50^{\mathrm{ns}}$ \\
$(\mathrm{n}=15)$ & $(61.40-87.60)$ & $(59.40-87.03)$ & \\
& $\mathrm{P}$ value & $\mathrm{P}$ value & \\
A vs B & $<0.001^{* * *}$ & $<0.001^{* * *}$ & \\
A vs C & $<0.001^{* * *}$ & $<0.001^{* * *}$ & \\
B vs C & $>0.10^{\text {ns }}$ & $>0.10^{\text {ns }}$ & \\
\hline
\end{tabular}

Figures in the parentheses indicate range. Comparison between right and left side done by unpaired Student's ' $t$ ' test and comparison between different age groups done by One-way ANOVA (PostHoc), ns $=$ not significant, $* * *=$ significant. 


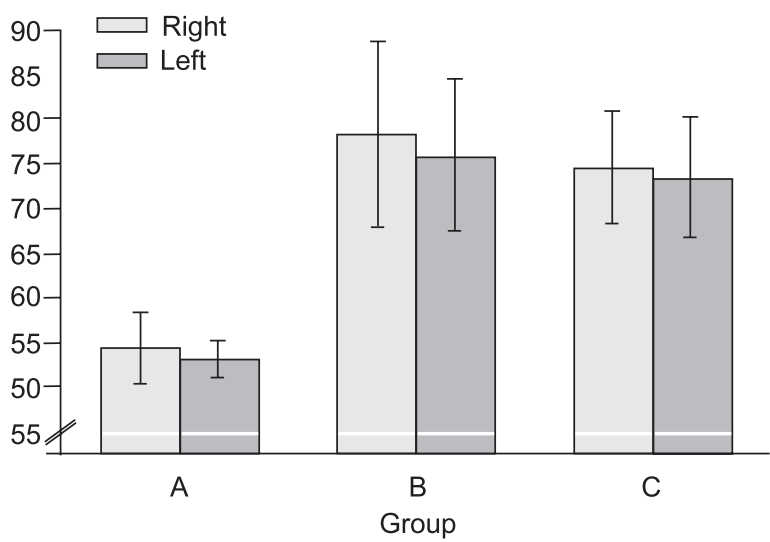

Fig. 1: Volume of right and left kidney in different age group.

\section{Discussion:}

Dunnill \& Halley $^{12}$ examined 68 pair of kidneys aged from birth to 90 years and found the combined volume of the both kidneys at birth about $20 \mathrm{ml}$. In healthy adults aged $20-25$ years it was about $250 \mathrm{ml}$ and in old age the volume declines. According to Rasmussen et al. ${ }^{13}$, there was no demonstrable difference between volumes of right and left kidneys, and no difference in relation to sex. Total renal volume was most accurate when correlated with the body weight and normal values of total renal volume in relation to body weight were found 4.3 to $8.0 \mathrm{ml} / \mathrm{kg}$. Emamian et al. ${ }^{11}$ examined 665 kidneys of both sexes, aged from 30 to 70 years, in Denmark, and found median renal volume $134 \mathrm{~cm}^{3}$ in the right and $146 \mathrm{~cm}^{3}$ in the left kidney. Besides, they concluded that renal size decreased with age, almost entirely because of parenchymal reduction; however, renal volume correlated best with total body area. Buchholz et al. ${ }^{14}$ performed ultrasonographic kidney measurements on 194 adult patients without known kidney lesions (98 male and 96 female) in Pakistan. The mean age was $44.7 \pm 14$ years (age range $13-80$ years) and mean kidney size (length $\times$ width $\times$ cortical thickness) was $76.16 \pm 21.7 \mathrm{~cm}^{3}$ (ranging from 36.8 to $138 \mathrm{~cm}^{3}$ ). They found the average size of the kidneys $70 \pm 22 \mathrm{~cm}^{3}$ (right kidney) and $82 \pm 24 \mathrm{~cm}^{3}$ (left kidney), with the right kidney being significantly smaller than the left. They also reported that the average size of the right kidneys were $77 \pm 22.6 \mathrm{~cm}^{3}$ in male and $63 \pm 18.1$ $\mathrm{cm}^{3}$ in female, while the average size of the left kidneys were found $90 \pm 25.7 \mathrm{~cm}^{3}$ in male and $74 \pm 20.3 \mathrm{~cm}^{3}$ in female, where female kidneys were significantly smaller than the male kidneys. Nomasa ${ }^{15}$ calculated the volume of the kidney in 442 kidneys in 221 normal children (15 neonates, 45 infants, 82 boys and 79 girls between 1 and 15 years of age) by using three-dimensional ultrasonography in Japan. The renal size ranged from $34.08 \pm 5.92 \mathrm{~cm}^{3}$ (right) and $34.58 \pm 3.70 \mathrm{~cm}^{3}$ (left) to $119.23 \pm 31.07$ $\mathrm{cm}^{3}$ (right) and $120.77 \pm 25.25 \mathrm{~cm}^{3}$ (left). Cheong et al. ${ }^{8}$ performed a retrospective study on 150 subjects; as measured by MRI, kidney volumes were $202 \pm 36 \mathrm{ml}$ for men and $154 \pm 33 \mathrm{ml}$ for women. Shin et al. ${ }^{16}$ retrospectively reviewed and evaluated the normal kidney volume in 113 young Korean men by using multi-detector computed tomography (MDCT) data; the mean kidney volume was $205.29 \pm 36.81 \mathrm{~cm}^{3}$. Raza et al. ${ }^{17}$ studied on 4,035 adult Pakistani subjects with normal serum creatinine and without any known renal disease and found the mean renal volume on right $99.8 \pm 37.2 \mathrm{~cm}^{3}$ and on left $124.4 \pm 41.3 \mathrm{~cm}^{3}$, as left renal size was significantly larger than right in both genders. The values of the present study were more or less similar to Buchholz ${ }^{14}$; however, much lower than that of others ${ }^{8,11-13,15-17}$.

The main disadvantage of autopsy studies for studying normal aging is that the underlying renal pathology may have contributed to the cause of death ${ }^{5}$. Another limitation of the cadaveric study is that measurements obtained from cadavers cannot be considered equivalent to those of living kidneys, because a large volume of blood circulates through a kidney ${ }^{15}$.

There is both increased volume of functional glomeruli and decreased glomerular density with aging, as thought to be responsible for shrinkage of kidney size with aging process ${ }^{18-}$ 21. Unlike, our study revealed that kidney volume increases with advancing age. A compensatory increase of the volume of unaffected nephrons in response to loss of nephrons affected by glomerulosclerosis and tubular atrophy has been suggested ${ }^{22}$. Besides, an increase in renal sinus fat with age may compensate for the decrease in the kidney 
parenchymal volume with age ${ }^{11,23}$. The difference in size of the kidney i.e. volume of the kidney in different age group or different periods of life may attribute to difference in body surface area or size change in renal mass in relation to age in a specified population ${ }^{24}$.

\section{Conclusion:}

No difference was found in volume between the right and the left kidney in any group. However, kidney volume was found to increase with advancing age in apparently healthy Bangladeshi people. The results of the present study can be used as a standard reference for the kidneys of Bangladeshi people and to determine the abnormal evidences in Forensic and Pathologic corpses. However, further studies with larger samples and comparison between sexes are recommended.

\section{Acknowledgement:}

We would like to express our gratitude to the authority of Health, Nutrition \& Population Sector Programme (HNPSP) of Directorate General of Health Services (DGHS) of the Government of the People's Republic of Bangladesh, and Dhaka Medical College, Dhaka, for the research grant.

\section{References:}

1. Lalli AF. Renal enlargement. Radiology 1965; 84: 688-91.

2. Jones TB, Riddick LR, Harpen MD, Dubuisson $\mathrm{RL}$, Samuels D. Ultrasonographic determination of renal mass and renal volume. J Ultrasound Med 1983; 2(4): 151-4.

3. Widjaja E, Oxtoby JW, Hale TL, Jones PW, Harden PN, McCall IW. Ultrasound measured renal length versus low dose CT volume in predicting single kidney glomerular filtration rate. Br J Radiol 2004; 77(921): 759-64.

4. Poggio ED, Hila S, Stephany B, Fatica R, Krishnamurthi V, del Bosque C, et al. Donor kidney volume and outcomes following live donor kidney transplantation. Am J Transplant 2006; 6(3): 616-24.

5. Glassock RJ, Rule AD. The implications of anatomical and functional changes of the aging kidney: with an emphasis on the glomeruli. Kidney Int 2012; 82(3): 270-7.
6. Shin HS, Chung BH, Lee SE, Kim WJ, Ha HI, Yang CW. Measurement of kidney volume with multi-detector computed tomography scanning in young Korean. Yonsei Med J 2009; 50(2): 262-5.

7. Bakker J, Olree M, Kaatee R, de Lange EE, Moons KG, Beutler JJ, et al. Renal volume measurements: accuracy and repeatability of US compared with that of MR imaging. Radiology 1999; $211(3)$ : 623-8.

8. Cheong B, Muthupillai R, Rubin MF, Flamm SD. Normal values for renal length and volume as measured by magnetic resonance imaging. Clin $\mathrm{J}$ Am Soc Nephrol 2007; 2(1): 38-45.

9. Sultana Z. An Anatomical study of human postmortem kidney in Bangladeshi people [thesis]. Dhaka: IPGMR, University of Dhaka; 1991.

10. Darmady EM, Offer J, Woodhouse MA. The parameters of the ageing kidney. J Pathol 1973; 109(3): 195-207.

11. Emamian SA, Nielsen MB, Pedersen JF, Ytte L. Kidney dimensions at sonography: correlation with age, sex, and habitus in 665 adult volunteers. Am J Roentgenol 1993; 160(1): 83-6.

12. Dunnill MS, Halley W. Some observations on the quantitative anatomy of the kidney. J Pathol 1973; 110(2): 113-21.

13. Rasmussen SN, Haase L, Kjeldsen H, Hancke S. Determination of renal volume by ultrasound scanning. J Clin Ultrasound 1978; 6(3): 160-4.

14. Buchholz NP, Abbas F, Biyabani SR, Afzal M, Javed Q, Rizvi I, et al. Ultrasonographic renal size in individuals without known renal disease. J Pak Med Assoc 2000; 50(1): 12-6.

15. Nomasa T. The standard renal volume of Japanese boys and girls determined by three-dimensional ultrasonography. Kurume Med J 2001; 48(2): 10510 .

16. Shin HS, Chung BH, Lee SE, Kim WJ, Ha HI, Yang CW. Measurement of kidney volume with multi-detector computed tomography scanning in young Korean. Yonsei Med J 2009; 50(2): 262-5.

17. Raza M, Hameed A, Khan MI. Ultrasonographic assessment of renal size and its correlation with body mass index in adults without known renal disease. J Ayub Med Coll Abbottabad 2011; 23(3): 64-8.

18. Goyal VK. Changes with age in the human kidney. Exp Gerontol 1982; 17(5): 321-31. 
19. Abdi R, Slakey D, Kittur D, Racusen LC. Heterogeneity of glomerular size in normal donor kidneys: impact of race. Am J Kidney Dis 1998; 32(1): 43-6.

20. McLachlan MS. The ageing kidney. Lancet 1978; 2(8081): 143-5.

21. Rule AD, Semret MH, Amer H, Cornell LD, Taler SJ, Lieske JC, et al. Association of kidney function and metabolic risk factors with density of glomeruli on renal biopsy samples from living donors. Mayo Clinic Proc 2011; 86(4): 282-90.
22. Hoy WE, Douglas-Denton RN, Hughson MD, Cass A, Johnson K, Bertram JF. A stereological study of glomerular number and volume: preliminary findings in a multiracial study of kidneys at autopsy. Kidney Int Suppl 2003; 83: 31-7.

23. Gourtsoyiannis N, Prassopoulos P, Cavouras D, Pantelidis $N$. The thickness of the renal parenchyma decreases with age: a CT study of 360 patients. Am J Roentgenol 1990; 155(3): 541-4.

24. Wein AJ, Kavoussi LR, Novick AC, Partin AW, Peters CA. eds. Campbell-Walsh Urology. $10^{\text {th }}$ ed. Saunders Elsevier; 2012. 